\title{
Library Services and Early Literacy Approaches in Public Libraries for Deaf and Hard of Hearing Children
}

Bobbie Bushman, University of North Texas

Keywords: Deaf/Hard of Hearing $(\mathrm{D} / \mathrm{HoH})$ patrons; early literacy; library services to children; patrons with disabilities

Publication Type: poster

\begin{abstract}
Children's librarians are challenged to provide inclusive programming in today's public libraries. There is a current trend in public libraries to provide special needs programming for children. This poster focuses on library programming for deaf and hard of hearing $(\mathrm{D} / \mathrm{HoH})$ children who visit U.S. public libraries. The American Library Association (ALA) states that hearing children need to know six pre-reading skills to be ready to read; however, some of these pre-reading skills focus on singing or rhyming, which are difficult for $\mathrm{D} / \mathrm{HoH}$ children.

This grounded theory research studies the programs, services, and story times that are implemented and modified for $\mathrm{D} / \mathrm{HoH}$ children in U.S. public libraries. This study began with sending out a recruitment script and questionnaire, which reached nearly 500 medium to large sized U.S. public libraries. Fifteen participants volunteered to be interviewed, and eleven were interviewed. Interviews were analyzed using open and axial coding, which is typical in grounded theory. Preliminary data and a review of literature on literacy acquisition for $\mathrm{D} / \mathrm{HoH}$ children suggested that $\mathrm{D} / \mathrm{HoH}$ children do not progress in four of the pre-reading skills outlined in the ALA's early literacy program, Every Child Ready to Read (ECRR), in the same way that hearing children do. Phonological awareness is largely not utilized by $\mathrm{D} / \mathrm{HoH}$ children in learning to read. $\mathrm{D} / \mathrm{HoH}$ children are also likely to build vocabulary, develop print motivation, and approach narrative skills differently than hearing children.

This grounded theory research developed the model of successful library services and modifications for $\mathrm{D} / \mathrm{HoH}$ children to explain which services, early literacy instruction, staff training and programs public libraries provide to children who are $\mathrm{D} / \mathrm{HoH}$. This research project also inquires about what kinds of modifications are made to serve $\mathrm{D} / \mathrm{HoH}$ children and what the impetus was for providing library services to deaf children. The first stage of the model highlights staff attitude as being warm and welcoming, taking initiative, and not seeing $\mathrm{D} / \mathrm{HoH}$ as a disability. The second stage described the impetus for providing services as encountering a $\mathrm{D} / \mathrm{HoH}$ patron in the library, knowing a disabled person in a librarian's personal life, or by encountering a nearby agency that serves $\mathrm{D} / \mathrm{HoH}$. In the third stage, librarians made accommodations by being inclusive in programming, providing ASL programming, or facilitating visual phonics instruction in place of phonological awareness instruction. In the fourth and final stage, this model reported outcomes such as educating both hearing and $\mathrm{D} / \mathrm{HoH}$ individuals and building a sense of community.
\end{abstract}




\section{The following references were consulted in the preparation of the abstract and poster.}

Allen, T., Letteri, A., Choi, S., \& Dang, D. (2014). Early visual language exposure and emergent literacy in preschool deaf children: Findings from a national longitudinal study. American Annals of the Deaf, 159(4), 346-358.

Aram, D., Most, T., \& Simon, A. (2008). Early literacy of kindergartners with hearing impairment: The role of mother-child collaborative writing. Topics in Early Childhood Special Education, 28(1), 31-41.

Aram, D., Most, T., \& Maylift, H. (2006). Contributions of mother-child storybook and joint writing to literacy development in kindergartens with hearing loss. Language, Speech and Hearing Services in Schools, 37(3), 209-223.

Banks, C. (2004). All kinds of flowers grow here: The children's place for children with special needs at Brooklyn Public Library. Children and Libraries, 2(1), 5-10.

Beal- Alverez, J., Lederberg, A. \& Easterbrooks, S. (2011). Grapheme-phoneme acquisition in deaf preschoolers. Journal of Deaf Studies and Deaf Education, 16(4), 1-22.

Bergeron, J., Lederberg, A., Easterbrooks, S., Miller, E., \& Connor, C. (2009). Building the alphabetic principle in young children who are deaf or hard of hearing. The Volta Review, 109(2), 87-119.

Blue, E., \& Pace D. (2011). UD and UDL: Paving the way toward inclusion and independence in the school library. Knowledge Quest 39(3), 48-55.

Center for Disease Control and Prevention (2015). Hearing loss in children: Treatment and intervention services. Retrieved June 14, 2016 from

http://www.cdc.gov/ncbddd/hearingloss/treatment.html.

Colin, S., Magnan, A., Ecalle, J., \& Leybaert, J. (2007). Relation between deaf children's phonological skills in kindergarten and word recognition in the first grade. Journal of Psychology and Psychiatry, 48(2), 139-146.

Dostal, H., \& Wolbers, K. A. (2014). Developing language and writing skills of deaf and hard of hearing students: A simultaneous approach. Literacy Research and Instruction, 53(3), 245-268

Easterbrooks, S. R. \& Beal-Alvarez, J. (2013). Literacy instructions for students who are deaf and hard of hearing. New York, NY: Oxford University Press.

Anonymous. (2006). Editorial: Educational practices and assessments. American Annals of the Deaf, 151(5), 461-463.

American Library Association (2011). Every child ready to read. Retrieved October 17, 2011, from http:/ /www.everychildreadytoread.org/

Gilliver, M., Cupples, L., Ching, T., Leigh, G. \& Gunnourie, M. (2016). Developing sound skills for reading: Teaching phonological awareness to preschoolers with hearing loss. Journal of Deaf Studies and Deaf Education, 21(3), 268-279.

Gioia, B. (2001). The emergent language and literacy experiences of three deaf preschoolers. 
International Journal of Disability, Development, and Education, 48(4) 411-428.

Goldin-Meadow, S. \& Mayberry, R. (2001) How do profoundly deaf children learn to read? Learning Disabilities Research and Practice, 16(4), 222-229.

Golos, D. (2010). Literacy behaviors of deaf preschoolers during video viewing. Sign Language Studies, 11(1), 76-99.

Hands, A. S., \& Johnson, A. (2012). Lighting the way: Grant applications showcase range of programming ideas. Children and Libraries, 10(2), 56-57.

Harrington, M., DesJardin, J., \& Shea, L. (2010). Relationships between early child factors and school readiness skills in young children with hearing loss. Communication Disorders Quarterly, 32(1), 50-62.

Hoffman, M., \& Wang, Y. (2010). The use of graphic representations of sign language in leveled texts to support deaf readers. American Annals for the Deaf, 155(2), 131-136.

Humphries, T., Kushalnagar, P., Mathur, G., Napoli, D. J., Padden, C., Rathmann, C., \& Smith, S. R. (2012). Language acquisition for deaf children: Reducing the harms of zero tolerance to the use of alternative approaches. Harm Reduction Journal, 9(1), 16.

Kaderavek, J. N., \& Pakulski, L. A. (2007). Mother-child storybook Interactions: Literacy orientation of preschoolers with hearing impairment. Journal of Early Childhood Literacy, 7(1), 49-72.

Kleeck, A., \& Schuele, C. (2010). Historical Perspectives on Literacy in Early Childhood. American Journal of Speech-Language Pathology, 19(4), 341-355.

Kyle, F., \& Harris, M. (2010). Predictors of reading development in deaf children: A 3-year longitudinal study. Journal of Experimental Child Psychology, 107(3), 229-243.

Lajoie, L. (2003). Embracing the silence: How librarians can help deaf children develop their reading skills. Library Journal. Retrieved from lj.libraryjournal.com/2003/08/ljarchives/embracing-the-silence/

Luckner, J. (2013). Using the dynamic indicators of basic early literacy skills with students who are deaf or hard of hearing: Perspectives of a panel of experts. American Annals of the Deaf, 158(1), 7-19.

Luckner, J., Bruce, S., \& Ferrell, K. (2016). Summary of the communication and literacy evidence-based practices for students who are deaf or hard of hearing, visually impaired, and deafblind. Communication Disorders Quarterly, 37(4), 225-241.

MacMilian, K. (2003). Signs of success: ASL access opens the door between deaf and hearing. Public Libraries 42(1), 17-9.

McCaffrey, M. (2004). The missing link. School Library Journal, 50(9), 48-9.

McCaffrey, M. (2004). Great books in sign language. School Library Journal, 50(12), 30.

Mounty, J., Pucci, C. \& Harmon, K. (2014). How deaf American sign Language/English bilingual children become proficient readers: An emic perspective. Journal of Deaf Studies and Deaf Education, 19(3), 333-346. 
Nail, S. (2008). ASL Tales bridges the gap between deaf and hearing children. Canadian Library Association, 54(6), 280-285.

Narr, R. (2006). Teaching phonological awareness with deaf and hard of hearing children. Teaching Exceptional Children, 38(4), 53-58.

National Center for Educational Statistics. (2016, May). Children with youth disabilities. Retrieved June 12, 2016 from http://nces.ed.gov/programs/coe/indicator_cgg.asp

National Center for Education Statistics (2003). National Assessment of Adult Literacy. Retrieved July 19, 2016 from http://nces.ed.gov/naal/kf_demographics.asp

National Center for Learning Disabilities. (2013). Screening tools. Get Ready to Read! Retrieved October 17, 2013 from http: //www.getreadytoread.org/screening-tools/

National Institute on Deafness and Other Communication Disorders. (2016, June 17). Hearing, ear infections, and deafness. Retrieved July 23, 2016, from https://www.nidcd.nih.gov/health/hearing-ear-infections-deafness

Noland, A. (2003). How Cleveland serves the deaf community. Public Libraries, 42(1), 20-1.

Pinellas Public Library Cooperate (2016). Deaf Literary Center: A bridge to the world of information. Retrieved from http://www.pplc.us/dlc/about.shtml

Plessow-Wolfson, S., \& Epstein, F. (2005). The experience of story-reading: Deaf children and hearing mothers' interaction at story time. American Annals of the Deaf, 150(4), 369-78.

Public Library Association \& Association for Library Service to Children. (2011). Every Child Ready to Read: A workshop for library staff [PowerPoint slides]. Retrieved from http://www.slideshare.net/NortheastLibrarySystem/every-child-ready-to-read-2ndedition-9529975

Robertson, L., Dow, G., \& Hainzinger, S. (2006). Story retelling patterns among children with and without hearing loss: Effects of repeated practice and parent-child attunement. The Volta Review, 106(2), 147-70.

Rodriguez, R., \& Reed, M. (2003). Our deaf family needs to read, too. Public Libraries, 42(1), 3841.

Rottenberg, C. (2001). A deaf child learns to read. American Annals of the Deaf, 146(3), 270-75.

Smith, A. \& Wang, Y. (2010). The impact of visual phonics on the phonological awareness and speech production of a study who is deaf: A case study. American Annals of the Deaf, 155(2), 124-130.

Stobbart, C. \& Alant, E. (2008). Home based literacy experiences of severely to profoundly deaf preschoolers and their hearing parents. Journal of Developmental and Physical Disabilities, 20(2), 139-53.

Strong, M., \& Prinz, P. M. (1997). A study of the relationship between American Sign Language and English literacy. Journal of Deaf Studies and Deaf Education, 2(1), 37-46.

Syverud, S. M., Guardino, C., \& Selnick, D. N. (2009). Teaching phonological skills to a deaf first grader: A promising strategy. American Annals of the Deaf, 154(4), 382-388. 
Toscano, R. M., McKee, B., \& Lepoutre, D. (2002). Success with academic English: Reflections of deaf college students. American Annals of the Deaf, 147(1), 5-23.

Webb, M. L., \& Lederberg, A. R. (2014). Measuring Phonological Awareness in Deaf and Hard-ofHearing Children. Journal Of Speech, Language \& Hearing Research, 57(1), 131-142.

Wemett, L. (2007). The Building Bridges Project: Library services to youth with disabilities. Children and Libraries, 5(3), 15-20.

White, B. (2011). The world in words and pictures: How graphic novels can help to increase the reading comprehension for students with hearing loss. Knowledge Quest, 39(3), 18-25.

Wolf, M. (2007). Proust and the squid: The story of science and the reading brain. New York, NY: HarperCollins.

Woolsey, M., Satterfield, S., \& Roberson, L. (2006). Visual phonics: An English code buster? American Annals of the Deaf, 151(4), 452-7.

World Health Organization (2015). Deafness and hearing loss. Retrieved May 12, 2016 from http://www.who.int/topics/deafness/en/

Bobbie Bushman (Bobbie.Bushman@unt.edu) received her Bachelor's of Science in Psychology in 2001 from Missouri State University in Springfield, MO, and worked as social worker for the mentally ill and deaf. After receiving her Master's of Library and Information Science in 2008 from the University of Missouri in Columbia, MO, Bobbie discovered her passion in libraries while working as Youth Services Manager at the Midtown Carnegie Library Branch of the SpringfieldGreene County Library in Springfield, MO. She left that position in 2010 to pursue her Ph.D. in Information Science and Learning Technologies from the University of Missouri in Columbia, MO. Bobbie is currently the Houston-based Program Coordinator and Information Science Lecturer at the University of North Texas in Denton, TX. She has taught classes with an emphasis on public libraries, services to children and young adults, and services to marginalized and special needs populations. Bobbie has completed research about library services to children with disabilities and early literacy approaches in the library for deaf/hard of hearing children. She has presented at other conferences on the topics such as The Invisible Minority: LGBTQ Teens and Their Literature. 